\title{
Effects of Reactor Pressure and Inlet Temperature on $n$-Butane/Dimethyl Ether Oxidation and the Formation Pathways of the Aromatic Species
}

\author{
Tugce Bekat ${ }^{a}$ and Fikret Inal ${ }^{b}$ \\ ${ }^{a}$ Department of Chemical Engineering, Yildiz Technical University, 34210 Istanbul, Turkey \\ bepartment of Chemical Engineering, Izmir Institute of Technology, 35430 Izmir, Turkey; fikretinal@iyte.edu.tr \\ (for correspondence)
}

Published online 1 July 2015 in Wiley Online Library (wileyonlinelibrary.com). DOI 10.1002/ep.12190

\begin{abstract}
Oxidation of n-butane/dimethyl ether (DME)/O $\mathrm{O}_{2} /$ Ar system was studied by chemical kinetic modeling in a tubular reactor operated adiabatically and at constant pressure. Effects of the reactor pressure on the formation of various major, minor, and trace oxidation products were investigated for two different pressures (1 and $5 \mathrm{~atm}$ ) and at six different inlet temperature values (700, 800, 900, 1100, 1300, and $1500 \mathrm{~K}$ ). The analysis was carried out for two different concentrations of dimethyl ether in the inlet fuel mixture (20 and $50 \mathrm{~mol} \%$ ). Higher pressure (5 atm) resulted in higher mole fractions of methane, vinylacetylene, and cyclopentadiene; and lower mole fractions of formaldebyde, acetylene, acetaldebyde, ethane, propargyl, and propane. The mole fractions of $\mathrm{CO}$ and $\mathrm{CO}_{2}$ were not affected considerably by the pressure change. The main formation routes of benzene were developed at two different inlet temperature values (1100 and $1300 \mathrm{~K}$ ), and the main precursors participating in these routes were found to be propargyl, propene, and diacetylene. A skeletal mechanism was developed for the oxidation of n-butane/DME mixture from the detailed mechanism by reduction of the elementary reactions by 79\%, and it was tested for accuracy by comparison with the data from the literature. (c) 2015 American Institute of Chemical Engineers Environ Prog, 35: 230-240, 2016
\end{abstract}

Keywords: dimethyl ether, n-butane, kinetic modeling, aromatics, skeletal mechanism

\section{INTRODUCTION}

Dimethyl ether $\left(\mathrm{CH}_{3} \mathrm{OCH}_{3}\right.$, DME) is an oxygenated alternative fuel and a fuel additive. Due to its similar physical and handling characteristics to liquefied petroleum gas (LPG), it is mainly used as a LPG additive or substitute. DME requires none or very little modification of the conventional equipment when blended with $n$-butane $\left(n-\mathrm{C}_{4} \mathrm{H}_{10}\right)$, propane $\left(\mathrm{C}_{3} \mathrm{H}_{8}\right)$, or LPG up to amounts around 20 vol \% [1,2]. China is currently the leading country in DME production, and more than $90 \%$ of the DME produced in China is blended with LPG for residential cooking and heating purposes [1].

\footnotetext{
Additional Supporting Information may be found in the online version of this article.

(C) 2015 American Institute of Chemical Engineers
}

As fuel, DME/LPG blend can be used in spark ignition (SI) engines of transportation vehicles. Lee et al. [3] investigated the performance, emissions characteristics, and combustion stability of an SI engine operated with DME/LPG blend. Stable engine operation has been reported to be possible with the addition of up to $20 \%$ by mass of DME. DME was also used as an ignition promoter in a compression ignition (CI) engine operated with LPG [4]. The combustion and $\mathrm{NO}_{\mathrm{x}}$ emission characteristics of LPG/DME blend in a counter-flow non-premixed flame were investigated by Lee et al. [5]. The maximum flame temperature increased and $\mathrm{NO}_{\mathrm{x}}$ emissions decreased with increasing DME mole fraction. Hu et al. [6] reported that ignition delay time decreased with increase in DME blending ratio in DME/n-butane $/ \mathrm{O}_{2} / \mathrm{Ar}$ mixture. For DME/n-butane blend, the effects of thermal stratification were also studied in a CI engine [7].

In a previous work, we studied the oxidation of nbutane/DME blend in a tubular reactor, for two different DME concentrations in the fuel mixture (20 and $50 \mathrm{~mol} \%$ ) and for two different equivalence ratios (2.6 and 3.0) at varying inlet temperatures [8]. Concentrations of various toxic species, such as $\mathrm{CO}$, aromatic species, and polycyclic aromatic hydrocarbons (PAHs) were found to decrease with increasing DME concentration. Increase in equivalence ratio, on the other hand, caused an increase in the formation of these toxic species.

The chemical oxidation mechanism of $n$-butane/DME blend alters with changing reaction conditions due to the temperature and pressure dependencies of the elementary reactions forming the oxidation mechanism. Therefore, in this study, we investigated the effects of reactor pressure on the formation of various major, minor, and trace oxidation products from the oxidation of the n-butane/DME blend in a tubular reactor at different reactor inlet temperatures. The oxidation was carried out at two different pressure values (1 and $5 \mathrm{~atm}$ ), for two different DME mole fractions in the inlet fuel mixture (20 and 50\%), and at six different inlet temperatures $(700,800,900,1100,1300$, and $1500 \mathrm{~K})$. A detailed chemical kinetic modeling was used. Special attention was paid to the formation of aromatic species and PAHs, since many of these species are known to be mutagenic and/or carcinogenic [9], and their formation mechanisms in oxidation and combustion processes are not yet well defined. 
Table 1. Inlet mole fractions of the fuels and the oxidizer in n- $\mathrm{C}_{4} \mathrm{H}_{10} / \mathrm{CH}_{3} \mathrm{OCH}_{3} / \mathrm{O}_{2} /$ Ar oxidation system.

\begin{tabular}{|c|c|c|c|c|}
\hline $\begin{array}{l}\text { Equivalence } \\
\text { ratio, } \phi\end{array}$ & $\begin{array}{l}\text { DME in } \\
\text { the fuel } \\
\text { mixture } \\
(\mathrm{mol} \%)\end{array}$ & $\mathbf{X}_{\mathbf{C} 4 H 10}$ & $\mathbf{X}_{\mathbf{C H} 3 \mathrm{OCH} 3}$ & $\mathbf{X}_{\mathrm{O} 2}$ \\
\hline \multirow[t]{3}{*}{2.6} & 0 & 0.0057 & 0.0 & 0.0143 \\
\hline & 20 & 0.0049 & 0.0012 & 0.0138 \\
\hline & 50 & 0.0035 & 0.0035 & 0.0129 \\
\hline
\end{tabular}

Table 2. Parameters investigated for the oxidation of n-butane/DME mixture.

\begin{tabular}{lccc}
\hline Parameter & $\begin{array}{c}\text { Concentration } \\
\text { of DME in } \\
\text { the fuel } \\
\text { investigated } \\
\text { (mol \%) }\end{array}$ & $\begin{array}{c}\text { Inlet } \\
\text { temperature, } \\
\mathbf{T}_{\mathbf{0}}(\mathbf{K})\end{array}$ & $\begin{array}{c}\text { Pressure } \\
\text { (atm) }\end{array}$ \\
\hline $\begin{array}{c}\text { Effects of } \\
\text { temperature } \\
\text { and pressure }\end{array}$ & 20 and 50 & $\begin{array}{c}700,800, \\
900,1100,1300, \\
\text { and 1500 }\end{array}$ & 1 and 5 \\
$\begin{array}{l}\text { Formation } \\
\text { pathways } \\
\text { of aromatic } \\
\text { species }\end{array}$ & $\begin{array}{c}\text { n-butane) } \\
\text { and } 50\end{array}$ & 1100 and 1300 & 1 \\
\hline
\end{tabular}

The main formation pathways and the main species leading to the formation of the first aromatic ring benzene $\left(\mathrm{C}_{6} \mathrm{H}_{6}\right)$ were investigated at different temperature ranges.

Detailed chemical kinetic mechanisms represent oxidation and combustion processes successfully, but their incorporation into multidimensional complex models often require tremendous effort and computer power. Therefore, simpler skeletal mechanisms are needed, which can still represent the process accurately in a wide range of operating conditions. In this study, the developed detailed chemical kinetic mechanism was reduced into a simpler skeletal mechanism to represent the oxidation of $n$-butane/DME mixture.

\section{METHOD}

\section{Development of the Detailed Chemical Kinetic Mechanism}

The chemical kinetic mechanism used in modeling of $n$ $\mathrm{C}_{4} \mathrm{H}_{10} / \mathrm{CH}_{3} \mathrm{OCH}_{3} / \mathrm{O}_{2} /$ Ar system was developed by the combination of the comprehensive oxidation mechanisms suggested in the literature for neat $n$-butane [10] and DME [11] oxidations. These two mechanisms selected due to their validity for wide ranges of operating conditions and comprehensiveness in terms of chemical species were merged, and the kinetic parameters of the common elementary reactions were adjusted. Thus, the chemical kinetic mechanism for the oxidation of $n$-butane/DME mixture was developed. It consisted of 201 chemical species undergoing 903 reversible elementary reactions. The detailed chemical kinetic mechanism is given in Ref. 12 and is available upon request.

The accuracy of the mechanism developed was tested by comparison with the experimental data available in the literature. It was compared with the experimental findings of Chakir et al. [13], who studied the oxidation of neat n-butane in a jet-stirred reactor at $937 \mathrm{~K}$ and $10 \mathrm{~atm}$. Using the same reactor specifications and process conditions employed pre-

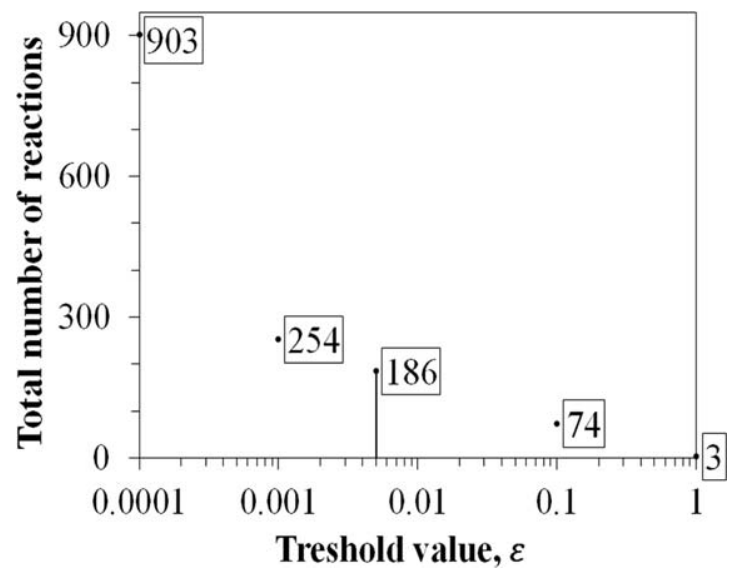

Figure 1. Total number of elementary reactions for different threshold values of normalized reaction contribution coefficients.

viously, mole fraction profiles of $n-\mathrm{C}_{4} \mathrm{H}_{10}, \mathrm{CO}, \mathrm{CO}_{2}$, and $\mathrm{C}_{2} \mathrm{H}_{4}$ (ethylene) were obtained with the detailed mechanism developed, and compared with the experimental data of Chakir et al. [13]. The results of this comparison were described in our previous work [8]. The mole fraction profiles of $n$ - $\mathrm{C}_{4} \mathrm{H}_{10}, \mathrm{CO}, \mathrm{CO}_{2}$, and $\mathrm{C}_{2} \mathrm{H}_{4}$ were successfully reproduced with the detailed mechanism, with only $\mathrm{CO}_{2}$ being slightly over predicted.

The detailed mechanism was also compared with the experimental data of Fischer et al. [14] who studied the oxidation of DME experimentally and theoretically in a flow reactor at $1086 \mathrm{~K}$ and $1 \mathrm{~atm}$. Reproducing the experimental data of Fischer et al. [14] with the detailed mechanism developed at the same operating conditions, mole fraction profiles of $\mathrm{CH}_{3} \mathrm{OCH}_{3}, \mathrm{O}_{2}$, and $\mathrm{CH}_{4}$ were successfully predicted, while $\mathrm{CH}_{2} \mathrm{O}$ (formaldehyde) mole fractions were slightly under predicted. The results of these comparisons were also presented in our previous work [8].

\section{Reactor Conditions}

The kinetic modeling of the $n-\mathrm{C}_{4} \mathrm{H}_{10} / \mathrm{CH}_{3} \mathrm{OCH}_{3} / \mathrm{O}_{2} / \mathrm{Ar}$ system was performed with Chemkin-Pro ${ }^{\circledR}$ software [15], using a tubular reactor with $10 \mathrm{~m}$ length and $0.05 \mathrm{~m}$ diameter. The flow through the reactor was laminar, with a gas velocity of $0.5 \mathrm{~m} / \mathrm{s}$. The plug-flow assumption in the reactor was validated according to the dispersion model [16], with the dispersion coefficients calculated below 0.01 for all conditions studied.

The reactor was operated at adiabatic conditions and at constant pressure. The inlet fuel and oxidizer mixture was diluted with Argon gas to maintain considerably low outlet temperatures. The mole fraction of Ar was 0.98 for all conditions studied (Table 1). Fuel-rich mixtures were selected since the formations of aromatic species and PAHs were of major concern, and these species are known to be mainly formed at fuel-rich oxidation conditions. Therefore, an equivalence ratio ( $\phi=(\text { fuel/oxidizer })_{\text {actual }}$ (fuel/oxidizer $\left.)_{\text {stoich }}\right)$ of 2.6 was used in this study.

\section{Investigation of the Effects of Process Parameters}

The effects of reactor pressure on the formation of major, minor, and trace species at different reactor temperatures were investigated (Table 2). Two different pressure values were selected as atmospheric condition (1 atm) and a higher pressure value $(5 \mathrm{~atm})$. The reactor was operated adiabatically at six different inlet temperatures (700, 800, 900, 1100, 1300 , and $1500 \mathrm{~K})$. 

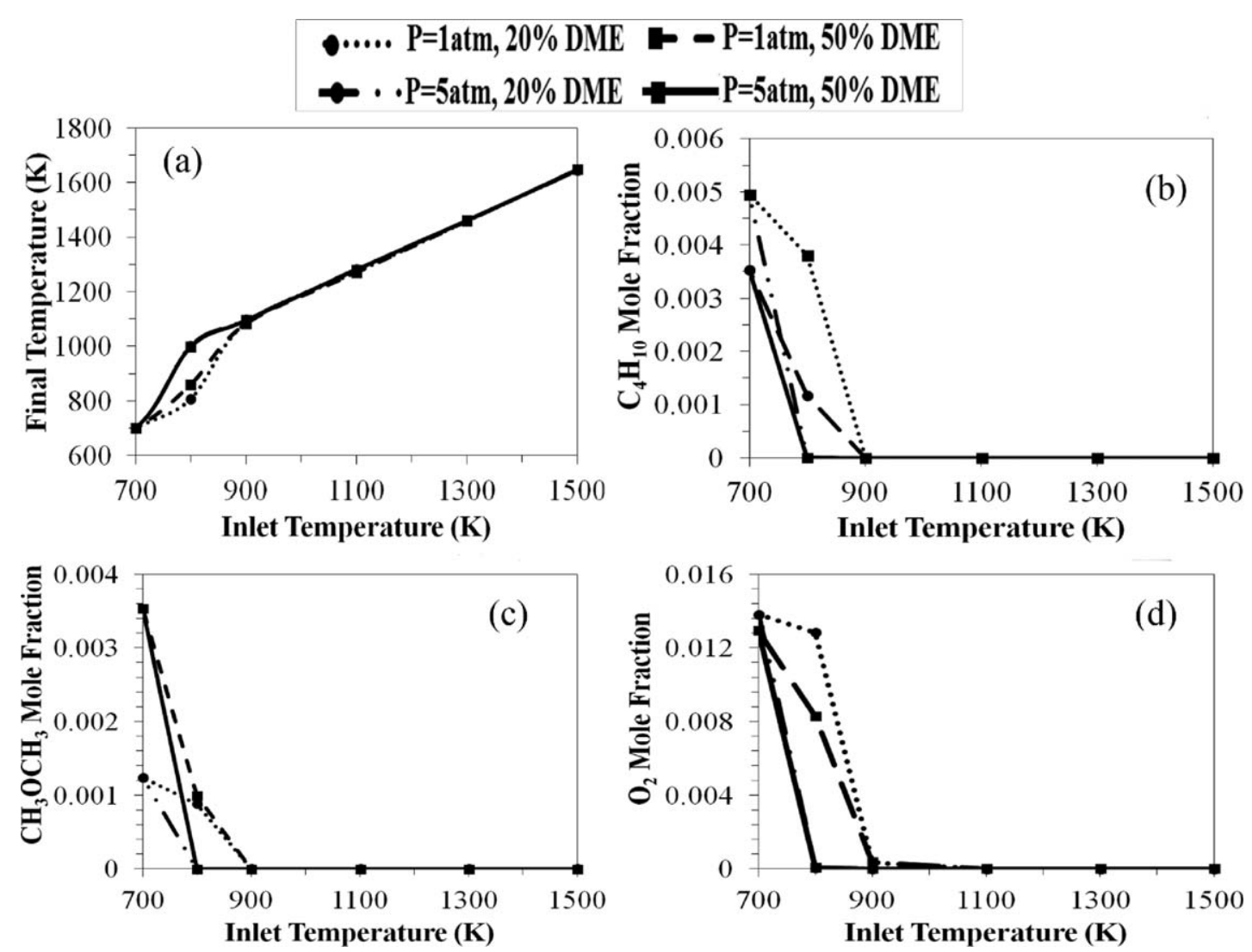

Figure 2. (a) Final reaction temperatures and mole fractions of (b) $\mathrm{C}_{4} \mathrm{H}_{10}$, (c) $\mathrm{CH}_{3} \mathrm{OCH}_{3}$, and (d) $\mathrm{O}_{2}$ at the reactor outlet.

Mole fractions of species at the reactor outlet were obtained for two different concentrations of DME in the fuel mixture (20 and $50 \mathrm{~mol} \%$ ), and presented as a function of reactor inlet temperature. The effects of varying DME concentration are not discussed here, since the results of this analysis were described in our previous work in detail [8].

\section{Investigation of the Formation Pathways of Aromatic Species}

The formation of the first aromatic ring and the consequent formations of higher aromatic species during oxidation of hydrocarbons are attributed to the reactions of various minor species as reported in the literature. These reactions will be discussed in more detail in Results and Discussion section. In this study, mole fractions of many of these minor species were investigated for n-butane/DME oxidation, together with mole fractions of the first aromatic ring $\mathrm{C}_{6} \mathrm{H}_{6}$ so that the relations between the formation of $\mathrm{C}_{6} \mathrm{H}_{6}$ and these minor species can be revealed. For this purpose, the concentration profiles of these minor species throughout the reactor were obtained, and compared with the concentration profile of $\mathrm{C}_{6} \mathrm{H}_{6}$.

The analysis was carried out for an inlet temperature of $1100 \mathrm{~K}$ at atmospheric pressure. The equivalence ratio was 2.6, and the mole fraction of DME in the feed fuel mixture was $50 \%$. The investigated minor species were $\mathrm{C}_{2} \mathrm{H}_{2}$ (acetylene), $\mathrm{C}_{2} \mathrm{H}_{4}$ (ethylene), $\mathrm{C}_{3} \mathrm{H}_{3}$ (propargyl), $\mathrm{aC}_{3} \mathrm{H}_{4}$ (allene), $\mathrm{pC}_{3} \mathrm{H}_{4}$ (propyne), $\mathrm{C}_{3} \mathrm{H}_{6}$ (propene), $\mathrm{C}_{4} \mathrm{H}_{2}$ (diacetylene), $\mathrm{C}_{4} \mathrm{H}_{4}$ (vinylacetylene), 1,3- $\mathrm{C}_{4} \mathrm{H}_{6}$ (1,3-butadiene), 1- $\mathrm{C}_{4} \mathrm{H}_{6}$ (1-butyne), $\mathrm{C}_{4} \mathrm{H}_{8}-1$ (but-1-ene), $\mathrm{C}_{4} \mathrm{H}_{8}-2$ (but-2-ene), and $\mathrm{c}_{-} \mathrm{C}_{5} \mathrm{H}_{6}$ (cyclopentadiene). The concentration profiles obtained for all the species were given for mole fractions above the order of $10^{-8}$.
In order to verify and extend the results of the comparison of the precursors and $\mathrm{C}_{6} \mathrm{H}_{6}$ concentration profiles, and also to identify the precursor species that play a major role in the formation of the first aromatic ring; a reaction path analysis was performed. This analysis ranks the elementary reactions that take part in the formation of a particular species according to their reaction rates, and determines the most important elementary reactions. The most important pathways leading to the formation of these particular species are shown in a reaction path diagram. The analysis was performed for an inlet temperature of $1100 \mathrm{~K}$ and for a higher temperature value of $1300 \mathrm{~K}$ (Table 2). The reaction was carried out under atmospheric pressure, and the equivalence ratio was 2.6. Neat $n$-butane and $n$-butane/DME (1:1) mixture oxidations were compared.

\section{Development of the Skeletal Mechanism for $\boldsymbol{n}$-Butane/ DME Oxidation}

After identification of the important species and pathways in the formations of the main oxidation products, the detailed chemical kinetic mechanism was reduced into a skeletal mechanism that represents the oxidation of the $n$ butane/DME mixture. Rate of Production Analysis was used for this purpose [17]. This analysis determines the contribution of each elementary reaction to the net production or destruction rates of a species. The contribution of reaction $i$ to the rate of production of species $k$ can be calculated as:

$C_{k i}=v_{k i} \cdot q_{i}$

where $C_{k i}$ is the chemical creation/destruction rate of the $k$ th species by the $i$ th reaction, $v_{k i}$ is the stoichiometric coefficient 

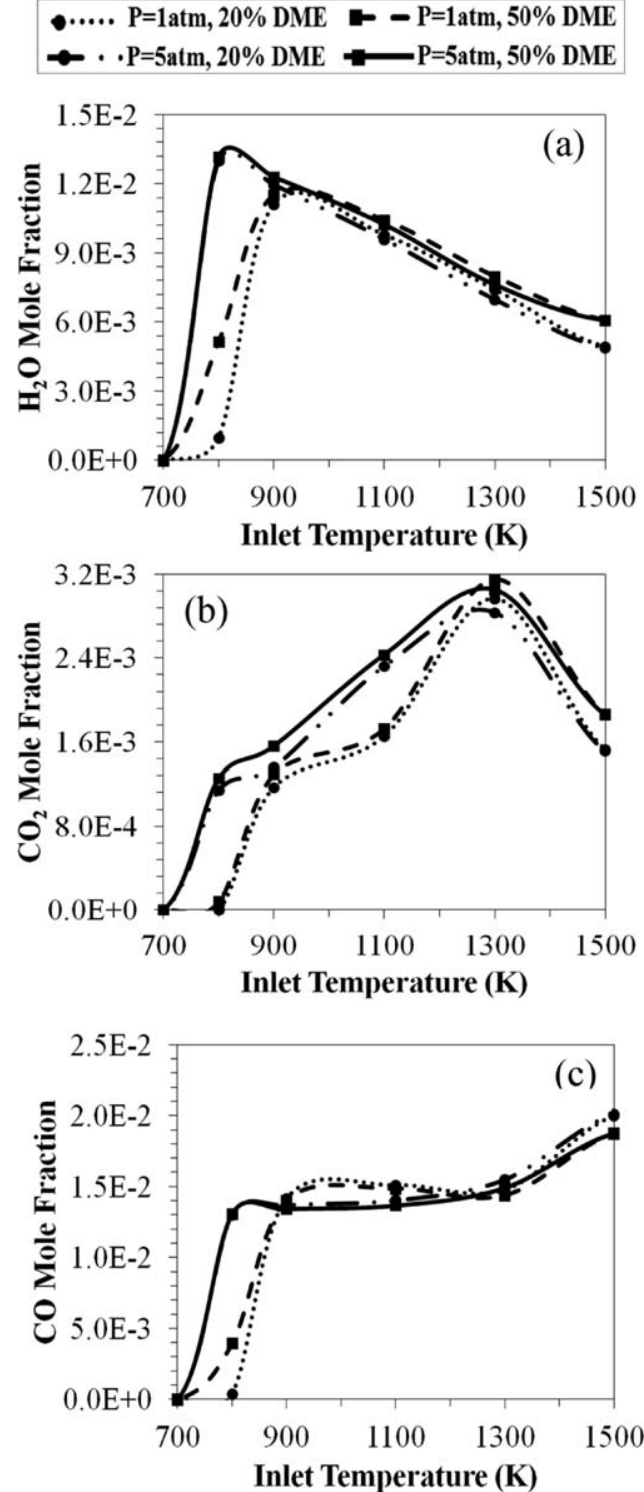

Figure 3. Mole fractions of (a) $\mathrm{H}_{2} \mathrm{O}$ (b) $\mathrm{CO}_{2}$ and (c) $\mathrm{CO}$ at the reactor outlet.

of the $k$ th species in the $i$ th reaction, and $q_{i}$ is the rate of progress of the $i$ th reaction. After the contributions of all the reactions to the rates of production of the selected species were calculated, the normalized values of these reaction contributions to the species production and destruction were determined using the following equations, respectively;

$\bar{C}_{k i}^{p}=\frac{\max \left(v_{k i}, 0\right) q_{i}}{\sum_{i=1}^{I} \max \left(v_{k i}, 0\right) q_{i}}$

$\bar{C}_{k i}^{d}=\frac{\min \left(v_{k i}, 0\right) q_{i}}{\sum_{i=1}^{I} \min \left(v_{k i}, 0\right) q_{i}}$

Then, a threshold value ( $\varepsilon$ ) was selected for the normalized contribution coefficients. The reactions with greater contribution coefficients were selected to be added to the skeletal mechanism, while the remaining reactions were omitted. The determination of the threshold value was a trial and error procedure. Various threshold values were tested,
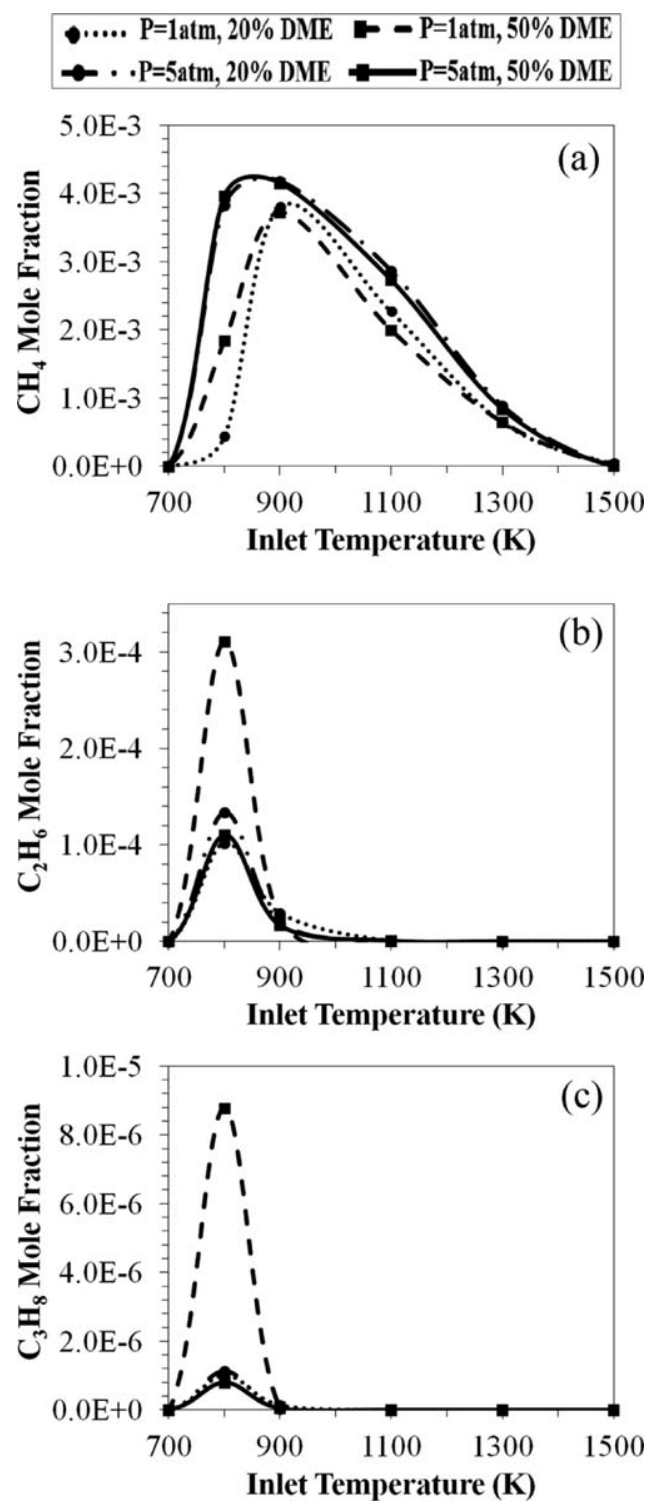

Figure 4. Mole fractions of (a) $\mathrm{CH}_{4}$, (b) $\mathrm{C}_{2} \mathrm{H}_{6}$, and (c) $\mathrm{C}_{3} \mathrm{H}_{8}$ at the reactor outlet.

resulting in different numbers of total elementary reactions (Figure 1). A larger threshold value resulted in smaller skeletal mechanism; however, this small mechanism should be capable of representing the $n$-butane/DME oxidation process correctly. Therefore, the resulting mechanisms were tested for accuracy, and the largest threshold value that produced an accurate set of elementary reactions was selected. This threshold value was $\varepsilon=0.005$.

\section{RESULTS AND DISCUSSION}

The Effects of the Process Parameters on the Formations of Reaction Products

The effects of reactor pressure on the formation of various species were investigated at six different inlet temperatures $(700,800,900,1100,1300$, and $1500 \mathrm{~K})$ and for two different concentrations of DME in the fuel mixture (20 and $50 \mathrm{~mol} \%$ ). The mole fractions of the major, minor, and trace species at the reactor outlet were given as a function of varying inlet temperatures. 

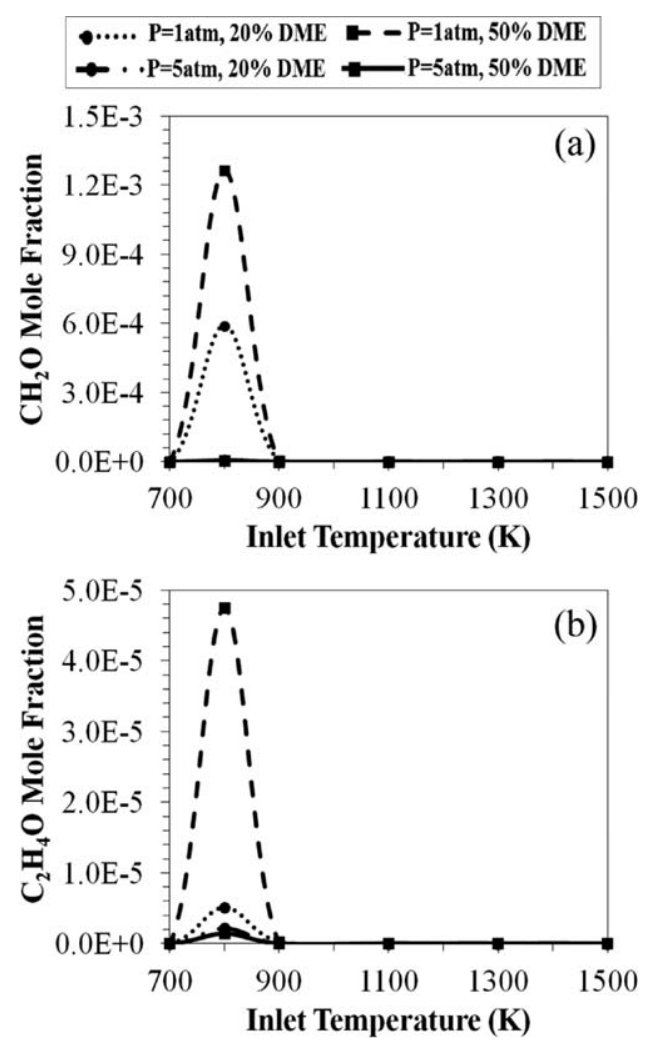

Figure 5. Mole fractions of (a) $\mathrm{CH}_{2} \mathrm{O}$ and (b) $\mathrm{C}_{2} \mathrm{H}_{4} \mathrm{O}$ at the reactor outlet.
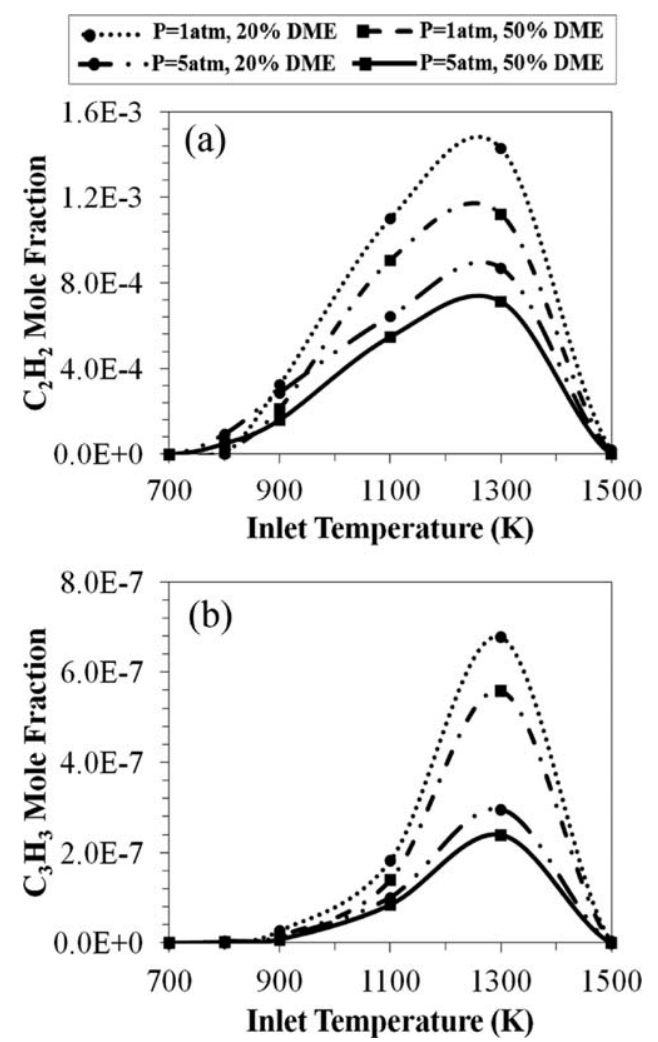

Figure 6. Mole fractions of (a) $\mathrm{C}_{2} \mathrm{H}_{2}$ and (b) $\mathrm{C}_{3} \mathrm{H}_{3}$ at the reactor outlet. 


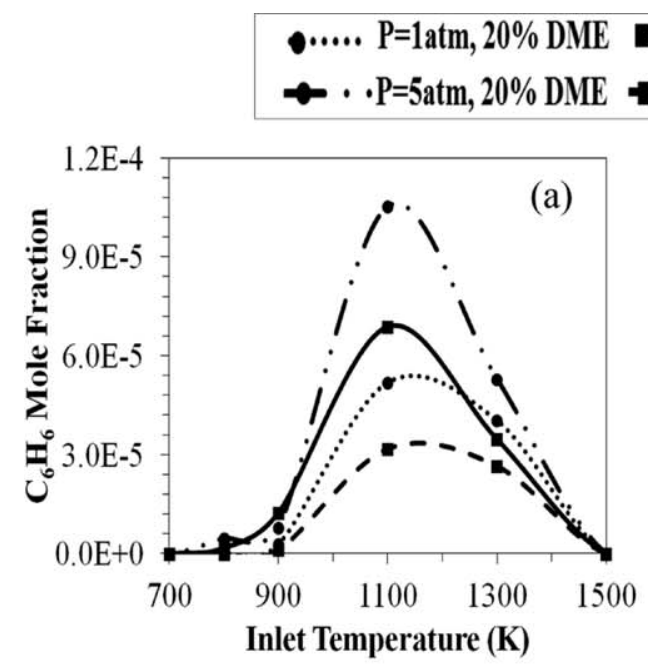

\section{- $\mathrm{P}=1 \mathrm{~atm}, 50 \% \mathrm{DME}$ \\ $P=5 a t m, 50 \%$ DME}
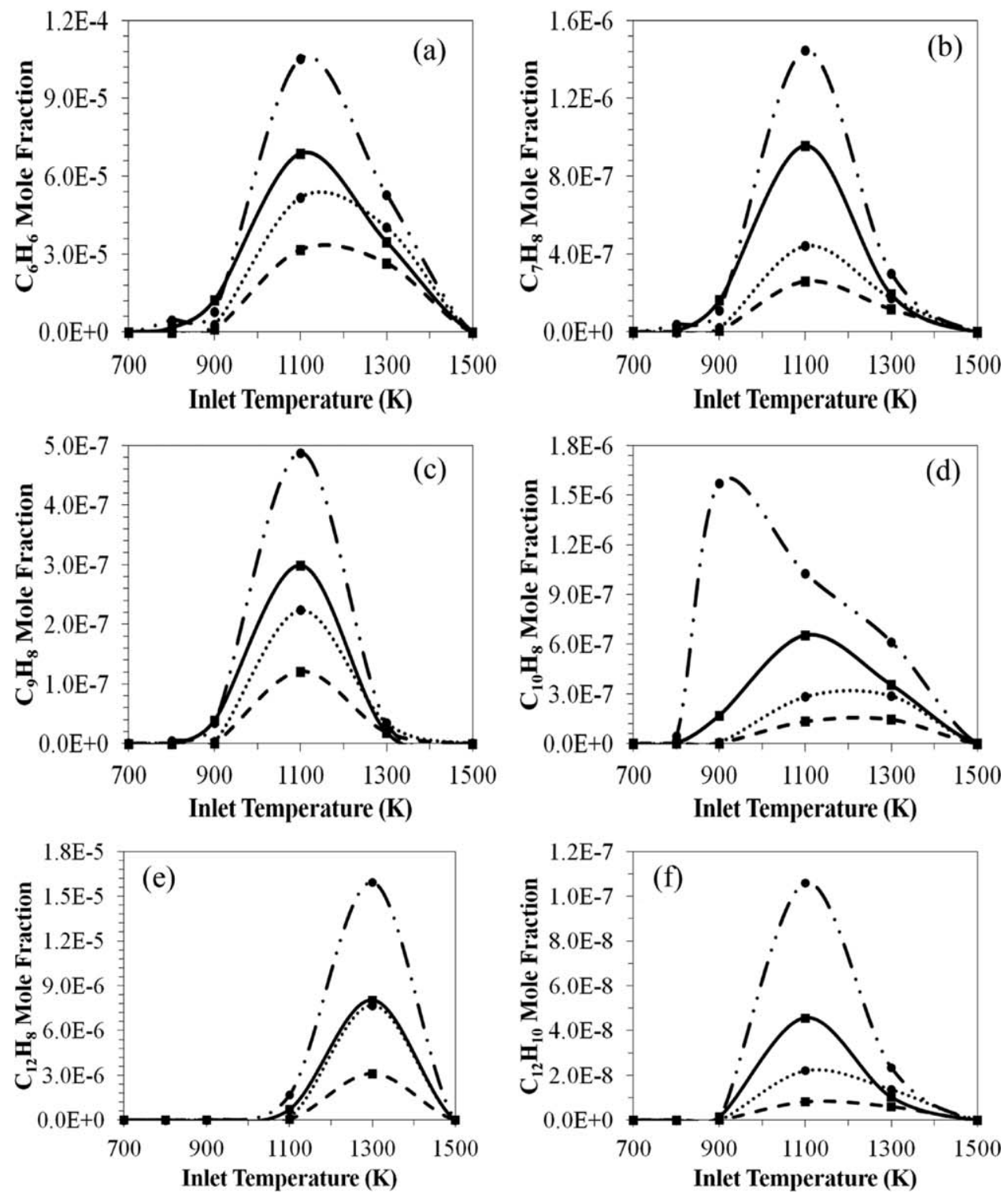

Figure 8. Mole fractions of (a) $\mathrm{C}_{6} \mathrm{H}_{6}$, (b) $\mathrm{C}_{7} \mathrm{H}_{8}$, (c) $\mathrm{C}_{9} \mathrm{H}_{8}$, (d) $\mathrm{C}_{10} \mathrm{H}_{8}$, (e) $\mathrm{C}_{12} \mathrm{H}_{8}$, and (f) $\mathrm{C}_{12} \mathrm{H}_{10}$ at the reactor outlet.

decline. The reactor pressure only affected $\mathrm{H}_{2} \mathrm{O}$ mole fraction in the incomplete reaction interval.

Two other major oxidation products are $\mathrm{CO}_{2}$ and $\mathrm{CO}$, and their final mole fractions are given in Figures $3 \mathrm{~b}$ and $3 \mathrm{c}$, respectively. The formation of $\mathrm{CO}_{2}$ increased until the inlet temperature of $1300 \mathrm{~K}$. Mole fraction of $\mathrm{CO}_{2}$ was slightly higher at $5 \mathrm{~atm}$. Above the inlet temperature of $1300 \mathrm{~K}$, the mole fraction of $\mathrm{CO}_{2}$ started to decrease with increasing inlet temperature, and the effect of pressure disappeared. Formation of $\mathrm{CO}$ first increased until $800 \mathrm{~K}$ at $5 \mathrm{~atm}$, and $900 \mathrm{~K}$ at 1 atm, and then it remained relatively constant until $1300 \mathrm{~K}$. Mole fraction of $\mathrm{CO}$ started to increase again at a moderate rate when the inlet temperature increased above $1300 \mathrm{~K}$. Among the reactions that participate in the production of $\mathrm{CO}$; $\mathrm{HCO}+\mathrm{M}=\mathrm{H}+\mathrm{CO}+\mathrm{M}, \mathrm{CH}_{2} \mathrm{CO}(+\mathrm{M})=\mathrm{CH}_{2}+\mathrm{CO}(+\mathrm{M})$, and $\mathrm{CH}_{3} \mathrm{CO}(+\mathrm{M})=\mathrm{CH}_{3}+\mathrm{CO}(+\mathrm{M})$ are known to be pressure dependent. However, for the conditions studied, the mole frac- tion of CO did not seem to be affected considerably by the reactor pressure. The effect of reactor pressure was more apparent on the mole fraction of $\mathrm{CO}_{2}$ up to the inlet temperature of $1300 \mathrm{~K}$.

Among the minor oxidation products, $\mathrm{CH}_{4}, \mathrm{C}_{2} \mathrm{H}_{6}$ (ethane), and $\mathrm{C}_{3} \mathrm{H}_{8}$ (propane) are alkane species with smaller carbon number than $n$-butane. $\mathrm{CH}_{4}$ formation is important due to its association with the global warming and climate change [18]. Mole fraction of $\mathrm{CH}_{4}$ increased with increasing temperature until $900 \mathrm{~K}$, and then started to decrease (Figure 4a). The lower reactor pressure (1 atm) resulted in slightly lower mole fractions of $\mathrm{CH}_{4}$ due to the pressure dependence of the following reaction; $\mathrm{CH}_{3}+\mathrm{H}(+\mathrm{M})=\mathrm{CH}_{4}(+\mathrm{M})$. This reaction makes a higher contribution to the formation of $\mathrm{CH}_{4}$, as the reaction temperature is increased. The other two alkanes, $\mathrm{C}_{2} \mathrm{H}_{6}$ and $\mathrm{C}_{3} \mathrm{H}_{8}$, had maximum mole fractions at $800 \mathrm{~K}$. Their mole fractions were lower than the mole fractions of 

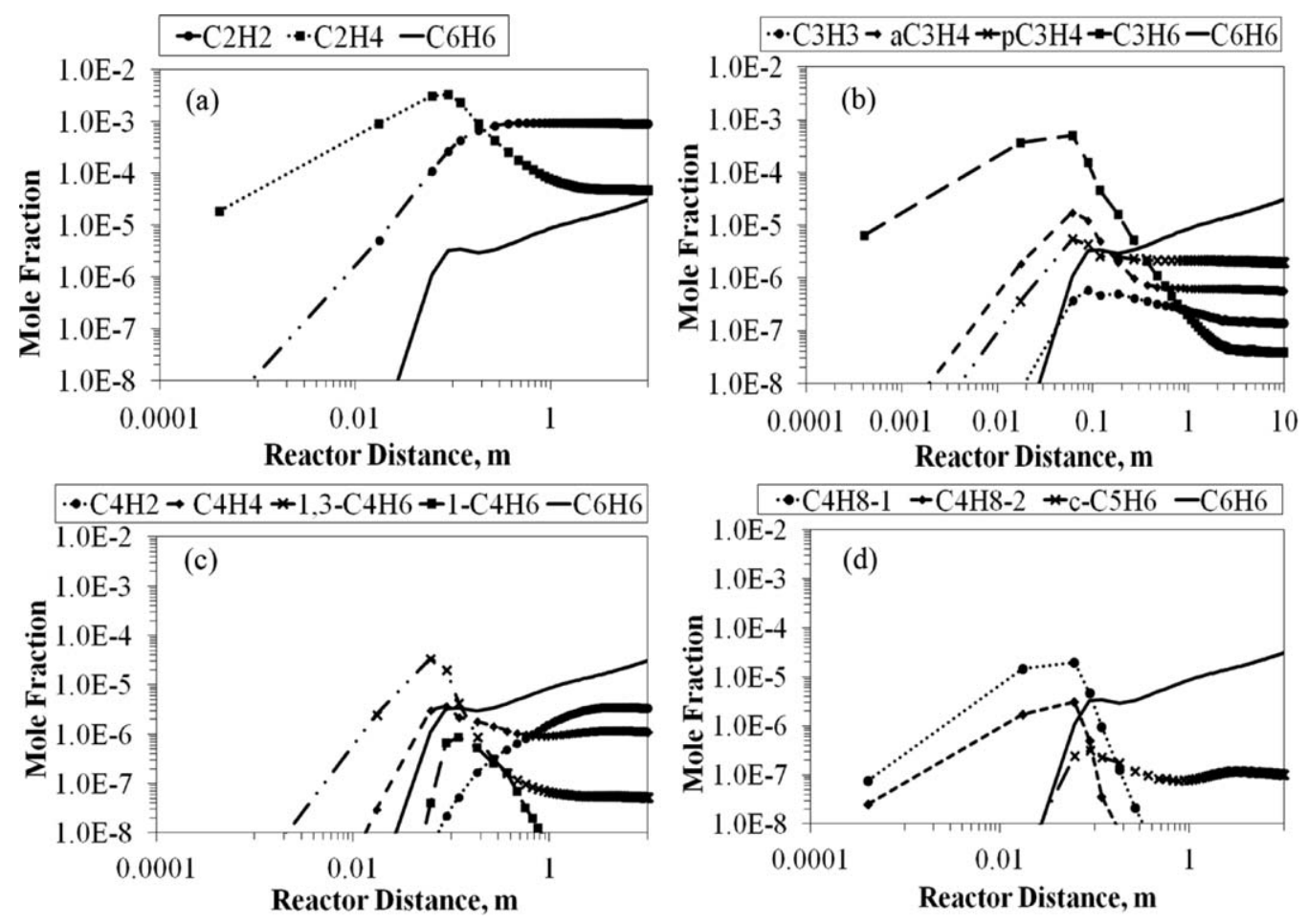

Figure 9. Concentration profiles of $\mathrm{C}_{6} \mathrm{H}_{6}$ and concentrations profiles of (a) $\mathrm{C}_{2} \mathrm{H}_{2}$ and $\mathrm{C}_{2} \mathrm{H}_{4}$, (b) $\mathrm{C}_{3} \mathrm{H}_{3}, \mathrm{aC}_{3} \mathrm{H}_{4}, \mathrm{pC}_{3} \mathrm{H}_{4}, a_{4} \mathrm{C}_{3} \mathrm{H}_{6}$, (c) $\mathrm{C}_{4} \mathrm{H}_{2}, \mathrm{C}_{4} \mathrm{H}_{4}, 1,3-\mathrm{C}_{4} \mathrm{H}_{6}$ and $1-\mathrm{C}_{4} \mathrm{H}_{6}$, and (d) $\mathrm{C}_{4} \mathrm{H}_{8}-1, \mathrm{C}_{4} \mathrm{H}_{8}-2$ and $\mathrm{c}_{-} \mathrm{C}_{5} \mathrm{H}_{6}$ for the oxidation of n-butane/DME (1:1) mixture. $\left(T_{0}=1100 \mathrm{~K}, P=1 \mathrm{~atm}\right.$, and $\left.\phi=2.6\right)$. ( $x$ - and $y$-axes are shown in logarithmic scale).

methane (Figures $4 \mathrm{~b}$ and $4 \mathrm{c}$ ). At the inlet temperature of $800 \mathrm{~K}$, the mole fractions of $\mathrm{C}_{2} \mathrm{H}_{6}$ and $\mathrm{C}_{3} \mathrm{H}_{8}$ were significantly higher for $1 \mathrm{~atm}$ and $50 \mathrm{~mol} \%$ DME case compared to other conditions studied. The higher DME concentration $(50 \mathrm{~mol} \%)$ decreased the mole fractions of $\mathrm{C}_{2} \mathrm{H}_{6}$ and $\mathrm{C}_{3} \mathrm{H}_{8}$, especially at $1 \mathrm{~atm}$, while it did not affect the mole fraction of $\mathrm{CH}_{4}$ notably.

Another group of minor oxidation products consists of $\mathrm{CH}_{2} \mathrm{O}$ (formaldehyde) and $\mathrm{C}_{2} \mathrm{H}_{4} \mathrm{O}$ (acetaldehyde), formations of which are known to increase by the addition of oxygenated fuel additives such as DME. These substances have carcinogenic effects in humans [19]. The mole fractions of these two aldehydes were considerable only below the inlet temperature of $900 \mathrm{~K}$ and at atmospheric pressure (Figure 5). It is known that the formations of these oxygenated compounds occur at low temperatures [20]. Although DME addition is known to decrease various emissions including toxic oxidation products, increased productions of these aldehydes are the main disadvantage of DME addition. The higher reactor pressure $(5 \mathrm{~atm})$ apparently prevented the formations of these species, even at $50 \mathrm{~mol} \% \mathrm{DME}$ concentration. The elementary reactions, $\mathrm{CHOCHO}(+\mathrm{M})=\mathrm{CH}_{2} \mathrm{O}+\mathrm{CO}(+\mathrm{M})$ and $\mathrm{CH}_{3} \mathrm{O}(+\mathrm{M})=\mathrm{CH}_{2} \mathrm{O}+\mathrm{H}(+\mathrm{M})$, that participate in $\mathrm{CH}_{2} \mathrm{O}$ mechanism are pressure dependent. Increasing pressure shifted the reactions toward the reactants side, decreasing the formation of $\mathrm{CH}_{2} \mathrm{O}$.

Published works have shown that some minor oxidation products are associated with the formation of aromatic compounds and PAHs [21-31]. Among these species, the mole fractions of $\mathrm{C}_{2} \mathrm{H}_{2}, \mathrm{C}_{3} \mathrm{H}_{3}, \mathrm{C}_{4} \mathrm{H}_{2}, \mathrm{C}_{4} \mathrm{H}_{4}$, and $\mathrm{c}-\mathrm{C}_{5} \mathrm{H}_{6}$ were investigated in this study. The higher reactor pressure $(5 \mathrm{~atm})$ decreased the mole fractions of $\mathrm{C}_{2} \mathrm{H}_{2}$ (Figure 6a), $\mathrm{C}_{3} \mathrm{H}_{3}$ (Figure 6b), and $\mathrm{C}_{4} \mathrm{H}_{2}$ (Figure $7 \mathrm{a}$ ), while increasing the mole fractions of $\mathrm{C}_{4} \mathrm{H}_{4}$ (Figure 7b) and $\mathrm{c}_{-} \mathrm{C}_{5} \mathrm{H}_{6}$ (Figure $7 \mathrm{c}$ ). DME was shown to decrease the formations of these precursor species in our previous study [8]. In this study, this decreasing effect seemed to be more dominant at the higher pressure. The mole fractions of $\mathrm{C}_{2} \mathrm{H}_{2}, \mathrm{C}_{3} \mathrm{H}_{3}$, and $\mathrm{C}_{4} \mathrm{H}_{2}$ reached their maximum values at the high inlet temperature range of $1300 \mathrm{~K}$ while $\mathrm{C}_{4} \mathrm{H}_{4}$ and $\mathrm{C}_{-} \mathrm{C}_{5} \mathrm{H}_{6}$ reached a maximum at the lower inlet temperature range of $900 \mathrm{~K}$. As these species are known to participate in the aromatics and PAHs formation, it can be said that changing temperature and pressure can alter the formation routes of aromatics and PAHs, and the role of participating precursors.

The trace oxidation products investigated were one-ring aromatics $\mathrm{C}_{6} \mathrm{H}_{6}, \mathrm{C}_{7} \mathrm{H}_{8}$ (toluene), and $\mathrm{C}_{9} \mathrm{H}_{8}$ (indene), and two-ring PAHs $\mathrm{C}_{10} \mathrm{H}_{8}$ (naphthalene), $\mathrm{C}_{12} \mathrm{H}_{8}$ (acenaphthylene), and $\mathrm{C}_{12} \mathrm{H}_{10}$ (biphenyl). The mole fractions of all of these aromatics increased in the case of the reactor pressure of $5 \mathrm{~atm}$, especially with the lower DME concentration (20 mol \%) (Figure 8). The highest mole fractions of $\mathrm{C}_{6} \mathrm{H}_{6}$, $\mathrm{C}_{7} \mathrm{H}_{8}, \mathrm{C}_{9} \mathrm{H}_{8}, \mathrm{C}_{10} \mathrm{H}_{8}$ (except for 5 atm and 20\% DME case), and $\mathrm{C}_{12} \mathrm{H}_{10}$ were observed at about $1100 \mathrm{~K}$ inlet temperature whereas the highest mole fraction of $\mathrm{C}_{12} \mathrm{H}_{8}$ was observed at $1300 \mathrm{~K}$.

\section{Investigation of the Formation Pathways of the Aromatic Species}

Formation pathways of the smaller aromatics and larger PAHs, and the contributing precursor species are not completely understood in oxidation and combustion processes. There are various species that contributed to the formations of the aromatics and PAHs in the literature [21-31]. For the oxidation of n-butane/DME mixture, the roles of the precursor species and the dominant pathways were tried to be clarified in this study.

The concentration profiles of the precursors investigated in the previous section and some other species that have 


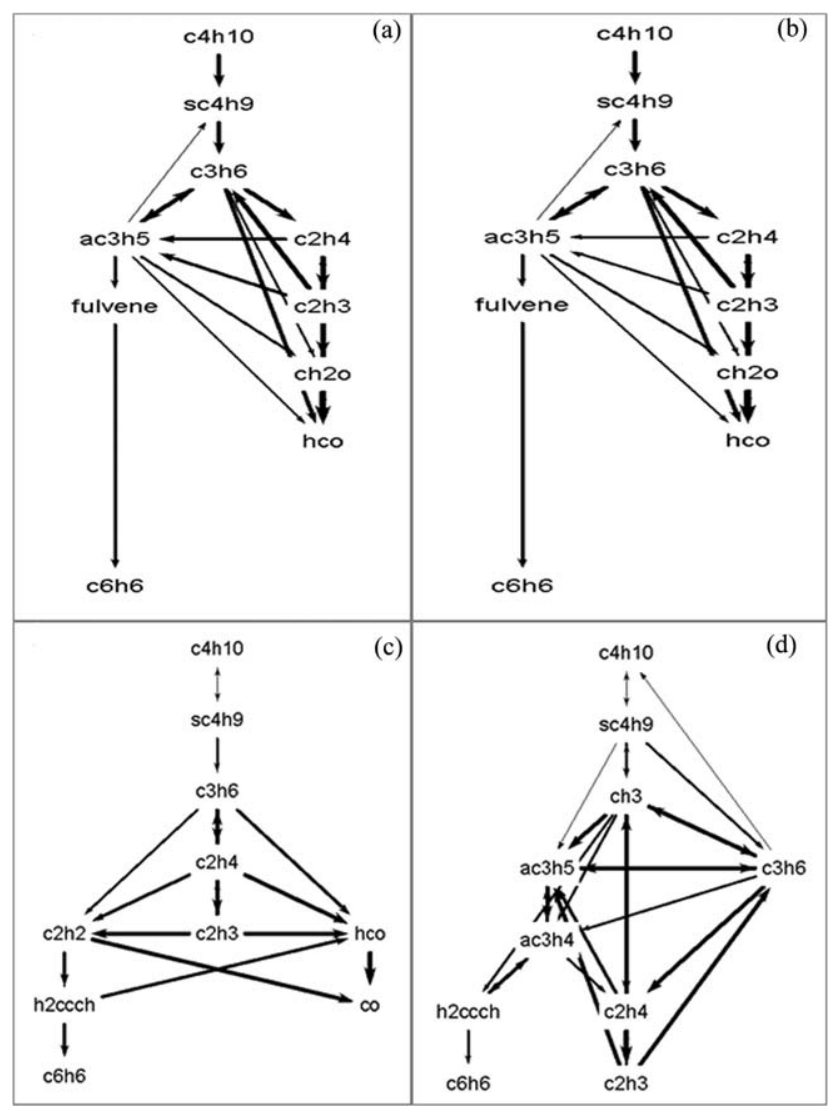

Figure 10. Main formation paths of $\mathrm{C}_{6} \mathrm{H}_{6}$ from $\mathrm{C}_{4} \mathrm{H}_{10}$ oxidation. (a) Neat $\mathrm{C}_{4} \mathrm{H}_{10}$ oxidation at $T_{0}=1100 \mathrm{~K}$, (b) $\mathrm{C}_{4} \mathrm{H}_{10} /$ $\mathrm{CH}_{3} \mathrm{OCH}_{3}$ (1:1) oxidation at $T_{0}=1100 \mathrm{~K}$, (c) neat $\mathrm{C}_{4} \mathrm{H}_{10}$ oxidation at $T_{0}=1300 \mathrm{~K}$, and (d) $\mathrm{C}_{4} \mathrm{H}_{10} / \mathrm{CH}_{3} \mathrm{OCH}_{3}$ (1:1) oxidation at $T_{0}=1300 \mathrm{~K}(P=1 \mathrm{~atm}$, and $\phi=2.6)$. Thicknesses of the arrows show the importance of the pathways.

been reported in the literature as aromatic precursors were obtained throughout the reactor and compared with the concentration profile of the first aromatic ring, $\mathrm{C}_{6} \mathrm{H}_{6}$. The analysis was carried out at $1100 \mathrm{~K}$, where most of the aromatics were observed to be produced in their highest amounts and the precursors were produced in observable amounts. Fuelrich conditions $(\phi=2.6)$ and atmospheric pressure were used. $n$-Butane and DME were equimolar in the feed mixture.

Formations of $\mathrm{C}_{3} \mathrm{H}_{6}, 1,3-\mathrm{C}_{4} \mathrm{H}_{6}, \mathrm{C}_{4} \mathrm{H}_{8}-1$, and $\mathrm{C}_{4} \mathrm{H}_{8}-2$ started at shorter reactor distances than the formation of $\mathrm{C}_{6} \mathrm{H}_{6}$, and were consumed almost entirely around the distance where $\mathrm{C}_{6} \mathrm{H}_{6}$ formation increased (Figure 9). This behavior suggested that these species most probably contributed to the early formation of $\mathrm{C}_{6} \mathrm{H}_{6}$ molecule. Among these species, $1,3-\mathrm{C}_{4} \mathrm{H}_{6}$ was proposed in the literature to play a role in the formation of the first aromatic ring and larger aromatics in oxidation of hydrocarbons [21].

Formations of $\mathrm{C}_{4} \mathrm{H}_{2}, 1-\mathrm{C}_{4} \mathrm{H}_{6}$, and $\mathrm{c}_{-} \mathrm{C}_{5} \mathrm{H}_{6}$ have started after the point where $\mathrm{C}_{6} \mathrm{H}_{6}$ formation had first occurred; suggesting that these species did not contribute to the initial formation of the first aromatic ring at this temperature range (Figure 9). These species might be taking role in the formations of larger aromatics. The roles of $\mathrm{C}_{4} \mathrm{H}_{2}$ [21] and $\mathrm{c}_{-} \mathrm{C}_{5} \mathrm{H}_{6}$ [22] in the formation of larger PAHs were previously reported in the literature.

The formation of $\mathrm{C}_{2} \mathrm{H}_{2}$ molecule started at early distances of the reactor; however, no consumption of $\mathrm{C}_{2} \mathrm{H}_{2}$ was observed where the formation of $\mathrm{C}_{6} \mathrm{H}_{6}$ started (Figure 9). This concentration trend suggested that $\mathrm{C}_{2} \mathrm{H}_{2}$ may not have played a significant role in $\mathrm{C}_{6} \mathrm{H}_{6}$ formation, but in larger aromatics. The role of $\mathrm{C}_{2} \mathrm{H}_{2}$ in the formations of larger aromatics and PAHs was explained by $\mathrm{H}$-abstraction $/ \mathrm{C}_{2} \mathrm{H}_{2}$-addition mechanism $[23,24] . \mathrm{C}_{2} \mathrm{H}_{2}$ was also suggested to participate in the initial formation of $\mathrm{C}_{6} \mathrm{H}_{6}$ around $1000 \mathrm{~K}[23,25]$; and to contribute by the reaction $\mathrm{C}_{4} \mathrm{H}_{5}+\mathrm{C}_{2} \mathrm{H}_{2} \rightarrow \mathrm{C}_{6} \mathrm{H}_{6}+\mathrm{H}$ [21]. However, our analysis showed that the role of $\mathrm{C}_{2} \mathrm{H}_{2}$ in the formation of larger aromatics should be much more dominant than its role in $\mathrm{C}_{6} \mathrm{H}_{6}$ formation around $1100 \mathrm{~K}$.

The concentration profiles showed that $\mathrm{C}_{2} \mathrm{H}_{4}, \mathrm{C}_{3} \mathrm{H}_{3}$, $\mathrm{aC}_{3} \mathrm{H}_{4}, \mathrm{pC}_{3} \mathrm{H}_{4}$, and $\mathrm{C}_{4} \mathrm{H}_{4}$ might have had only a little contribution to the formation of $\mathrm{C}_{6} \mathrm{H}_{6}$ around $1100 \mathrm{~K}$ (Figure 9). Previously, the roles of $\mathrm{C}_{3} \mathrm{H}_{3}$ in $\mathrm{C}_{6} \mathrm{H}_{6}[26,27]$ and larger PAHs $[28,29]$ formations were suggested. The roles of $\mathrm{C}_{2} \mathrm{H}_{4}[29,30]$, $\mathrm{aC}_{3} \mathrm{H}_{4}$ and $\mathrm{pC}_{3} \mathrm{H}_{4}$ [31], and $\mathrm{C}_{4} \mathrm{H}_{4}$ [21] in the formations of aromatic compounds were also discussed in the literature.

For further identification of the precursors that play a major role in the formation of $\mathrm{C}_{6} \mathrm{H}_{6}$, reaction path analysis was performed. First, the analysis was carried out at the same inlet temperature $(1100 \mathrm{~K})$ and pressure $(1 \mathrm{~atm})$. The cases of neat $n$-butane oxidation and equimolar $n$-butane/ DME oxidation were compared. The main formation route of $\mathrm{C}_{6} \mathrm{H}_{6}$ from $n$-butane did not change with the addition of DME at this temperature range (Figures $10 \mathrm{a}$ and 10b). The most important precursor among the species previously investigated seemed to be $\mathrm{C}_{3} \mathrm{H}_{6}$. The $\mathrm{C}_{2} \mathrm{H}_{4}$ molecule also contributed to $\mathrm{C}_{6} \mathrm{H}_{6}$ formation. However, its contributions to the formations of $\mathrm{CH}_{2} \mathrm{O}$ and $\mathrm{CO}$ (through $\mathrm{HCO}$ molecule) were more prominent.

The analysis was also carried out for a higher inlet temperature of $1300 \mathrm{~K}$, since some precursors and aromatics were observed to reach their highest mole fractions around this temperature range. In this case, the addition of DME affected the main route to $\mathrm{C}_{6} \mathrm{H}_{6}$ formation (Figures 10c and $10 \mathrm{~d}$ ). For neat $n$-butane oxidation, $\mathrm{C}_{3} \mathrm{H}_{6}$ and $\mathrm{C}_{2} \mathrm{H}_{4}$ maintained their roles to be the main species in the route, similar to the $1100 \mathrm{~K}$ case. However, $\mathrm{C}_{2} \mathrm{H}_{2}$ and $\mathrm{C}_{3} \mathrm{H}_{3}$ were observed to have important roles in the first aromatic ring formation. These four precursor species also participated in the formation of CO. In the case of n-butane/DME oxidation, the main precursor species were again $\mathrm{C}_{3} \mathrm{H}_{6}, \mathrm{C}_{2} \mathrm{H}_{4}$, and $\mathrm{C}_{3} \mathrm{H}_{3}$; but the role of $\mathrm{C}_{2} \mathrm{H}_{2}$ disappeared. The formation of $\mathrm{C}_{6} \mathrm{H}_{6}$ also decreased considerably, indicated by the reduced thickness of the arrow in the path. $\mathrm{CH}_{2} \mathrm{O}$ was not observed at this temperature for n-butane/DME mixture, which is known to be effective at lower oxidation temperatures. These findings were consistent with the other results obtained in this study.

\section{Skeletal Mechanism for $\boldsymbol{n}$-Butane/DME Oxidation}

After the determination of a suitable threshold value, a skeletal mechanism of 186 elementary reactions with 102 species was developed to represent the oxidation of $n$ butane/DME mixture using Rate of Production Analysis. The mechanism is given in the Supporting Information.

The accuracy of the skeletal mechanism was tested by comparison with the literature [32]. Since no data could be obtained for the oxidation of $n$-butane/DME mixture, the comparison was made with the oxidations of $\mathrm{CH}_{4} / \mathrm{DME}$ and $\mathrm{C}_{2} \mathrm{H}_{6} /$ DME mixtures. An accurate skeletal mechanism should also be effective in representing the mechanisms of $\mathrm{CH}_{4} /$ DME and $\mathrm{C}_{2} \mathrm{H}_{6}$ /DME oxidations, since they are the submechanisms of the $n$-butane/DME oxidation. A comparison with the results of the detailed mechanism was also performed.

Yoon et al. [32] have studied the effect of mixing DME with hydrocarbon fuels on $\mathrm{PAH}$ and soot formation in 
(a)

(b)

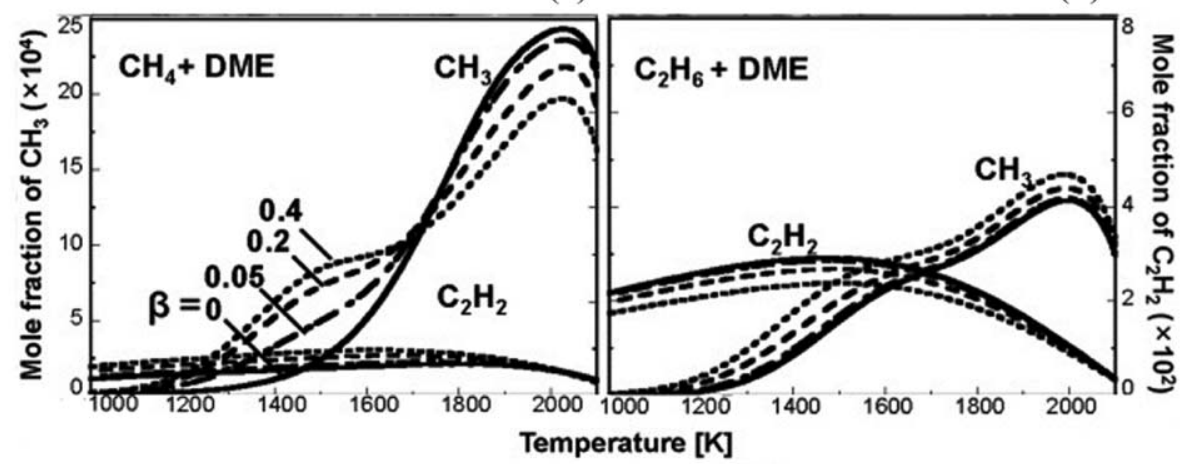

(c)

(d)

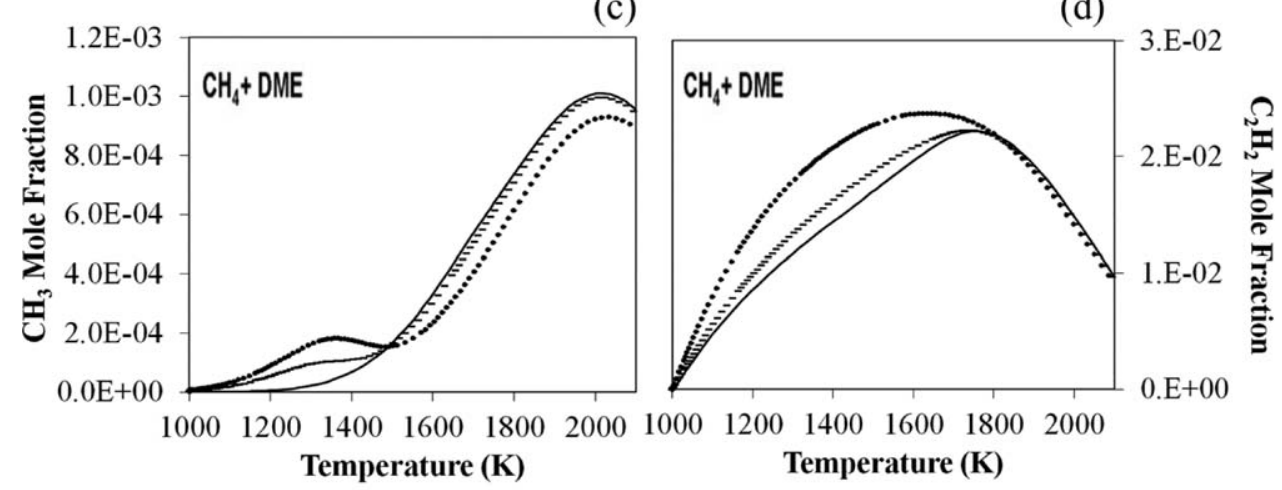

(e)
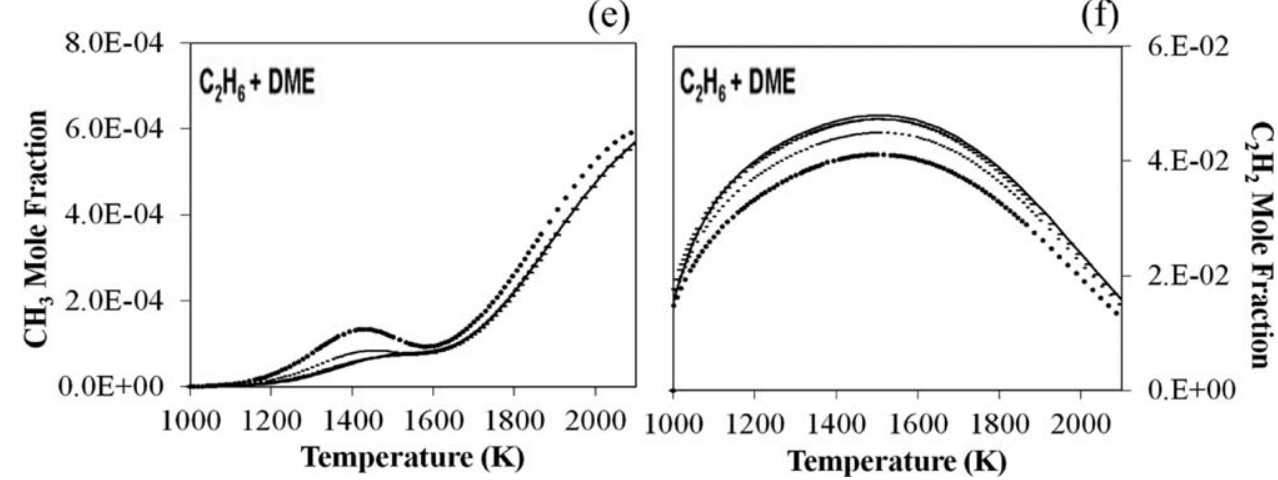

Figure 11. Validation of the skeletal chemical kinetic mechanism for $\mathrm{CH}_{4} / \mathrm{CH}_{3} \mathrm{OCH}_{3}$ and $\mathrm{C}_{2} \mathrm{H}_{6} / \mathrm{CH}_{3} \mathrm{OCH}_{3}$ oxidations by comparison with the results of Yoon et al. [32] (opposed - flow flames at $1 \mathrm{~atm}, \beta$ is the fraction of DME in the fuel mixture). Figures show the results of Yoon et al. for (a) $\mathrm{CH}_{4} / \mathrm{CH}_{3} \mathrm{OCH}_{3}$ oxidation and (b) for $\mathrm{C}_{2} \mathrm{H}_{6} / \mathrm{CH}_{3} \mathrm{OCH}_{3}$ oxidation, and the results of the skeletal mechanism for (c) $\mathrm{CH}_{3}$ and (d) $\mathrm{C}_{2} \mathrm{H}_{2}$ in $\mathrm{CH}_{4} / \mathrm{CH}_{3} \mathrm{OCH}_{3}$ oxidation and (e) $\mathrm{CH}_{3}$ and (f) $\mathrm{C}_{2} \mathrm{H}_{2}$ in $\mathrm{C}_{2} \mathrm{H}_{6} / \mathrm{CH}_{3} \mathrm{OCH} 3$ oxidation. (a) and (b) Reprinted from Yoon et al., Combustion and Flame, 2008, 154, 368-377 with permission from (c) Elsevier.

counterflow diffusion flames. Both experimental and modeling studies have been performed. $\mathrm{PAH}$ and soot concentrations were measured using laser induced fluorescence (LIF) and laser induced incandescence (LII) methods, respectively. The concentrations of $\mathrm{CH}_{3}$ and $\mathrm{C}_{2} \mathrm{H}_{2}$ were determined using a reaction mechanism containing 115 species and 602 reaction steps. For comparison with the $\mathrm{CH}_{4} / \mathrm{DME}$ and $\mathrm{C}_{2} \mathrm{H}_{6} / \mathrm{DME}$ oxidations, the numerical simulation results of Yoon et al. [32] were used. They studied $\mathrm{CH}_{4} / \mathrm{DME}$ and $\mathrm{C}_{2} \mathrm{H}_{6} / \mathrm{DME}$ oxidations in opposed-flow flames at atmospheric pressure and at various temperatures for four different mole fractions ( 0 , 5 , 20, and 40\%) of DME in the fuel mixture. The mole fractions of $\mathrm{CH}_{3}$ and $\mathrm{C}_{2} \mathrm{H}_{2}$ were reproduced using the skeletal mechanism under the same operating conditions. Figure 11 shows that the trends and the orders of the mole fractions of the species were predicted successfully by the skeletal mechanism.

The results of the comparison with the detailed mechanism are presented in Figure 12. Mole fraction profiles of $\mathrm{C}_{2} \mathrm{H}_{2}, \mathrm{C}_{3} \mathrm{H}_{3}, \mathrm{C}_{6} \mathrm{H}_{6}$, and $\mathrm{C}_{16} \mathrm{H}_{10}$ (pyrene, a 4-ring $\mathrm{PAH}$ ) against inlet temperatures were reproduced with the skeletal mechanism, and compared with the profiles obtained with the detailed mechanism. The skeletal mechanism was successful in predicting the mole fractions of $\mathrm{C}_{3} \mathrm{H}_{3}$ and $\mathrm{C}_{16} \mathrm{H}_{10}$, while it slightly under predicted the mole fractions of $\mathrm{C}_{2} \mathrm{H}_{2}$ and $\mathrm{C}_{6} \mathrm{H}_{6}$.

Although the skeletal mechanism developed requires further verification with experimental data from $n$-butane/DME oxidation, it can still be used in complex multidimensional models instead of the detailed mechanism, providing simplicity without much sacrifice from accuracy. 

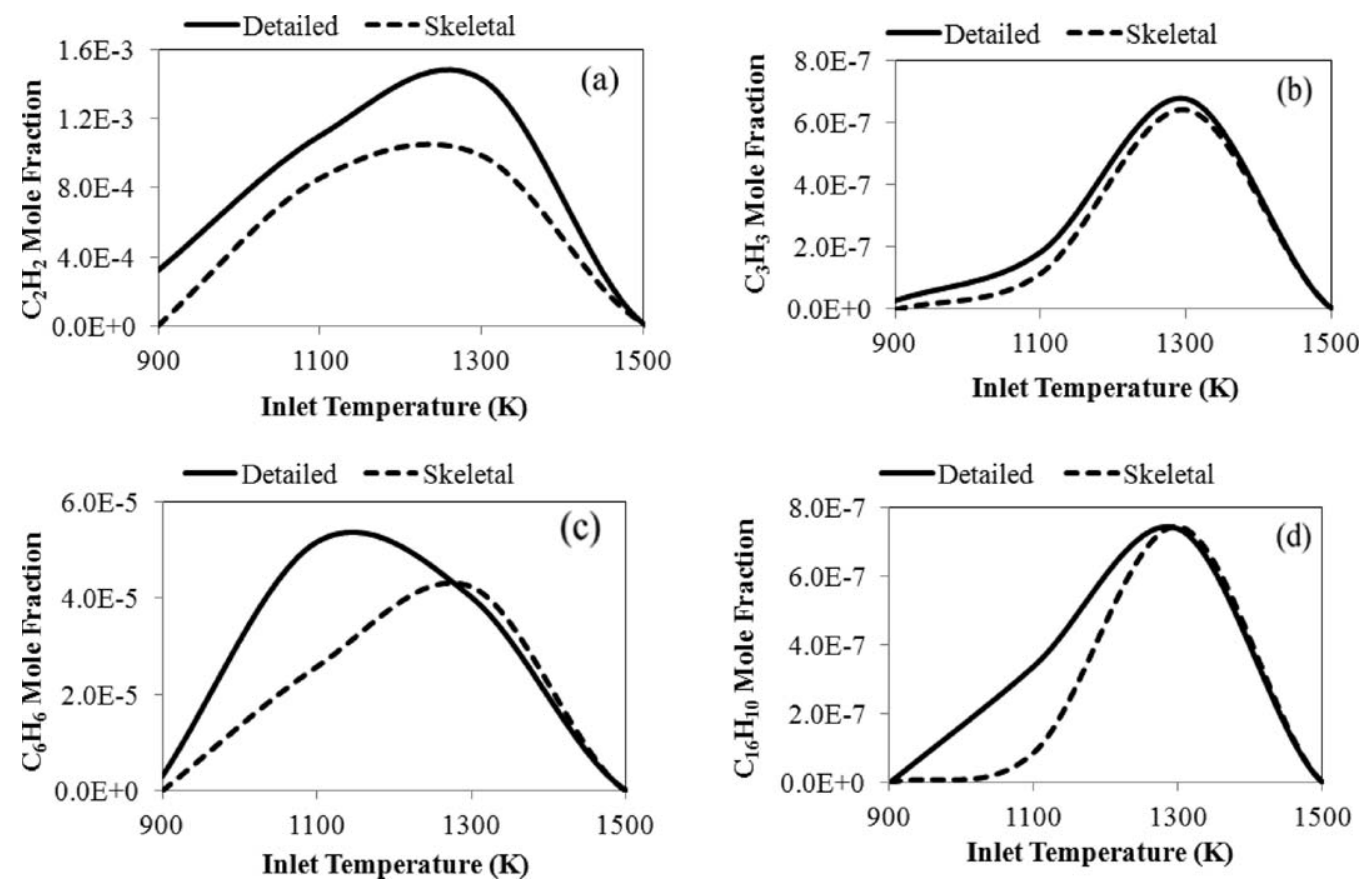

Figure 12. Comparison of the results of the skeletal mechanism with the results of the detailed mechanism; mole fractions of (a) $\mathrm{C}_{2} \mathrm{H}_{2}$, (b) $\mathrm{C}_{3} \mathrm{H}_{3}$, (c) $\mathrm{C}_{6} \mathrm{H}_{6}$, and (d) $\mathrm{C}_{16} \mathrm{H}_{10}$ for the oxidation of $n$-butane/DME (1:1) mixture. $\left(T_{0}=1100 \mathrm{~K}, P=1\right.$ atm, and $\phi=2.6$ ).

\section{CONCLUSIONS}

The oxidation of $n-\mathrm{C}_{4} \mathrm{H}_{10} / \mathrm{CH}_{3} \mathrm{OCH}_{3} / \mathrm{O}_{2} / \mathrm{Ar}$ system was studied by chemical kinetic modeling in a tubular reactor operating at two different pressures and at six different inlet temperatures, for two different concentrations of DME in the inlet fuel mixture. The effects of reactor pressure at different temperatures on the formations of various oxidation products were investigated. The mole fractions of $\mathrm{CH}_{4}, \mathrm{C}_{4} \mathrm{H}_{4}, \mathrm{c}_{-} \mathrm{C}_{5} \mathrm{H}_{6}$ and the aromatic species were found to increase with increasing pressure while the mole fractions of $\mathrm{C}_{2} \mathrm{H}_{6}, \mathrm{C}_{3} \mathrm{H}_{8}$, $\mathrm{CH}_{2} \mathrm{O}, \quad \mathrm{C}_{2} \mathrm{H}_{4} \mathrm{O}, \quad \mathrm{C}_{2} \mathrm{H}_{2}, \mathrm{C}_{3} \mathrm{H}_{3}$, and $\mathrm{C}_{4} \mathrm{H}_{2}$ were found to decrease. The mole fractions of $\mathrm{CO}$ and $\mathrm{CO}_{2}$ were not affected significantly by the change in pressure.

Maximum mole fractions of $\mathrm{H}_{2} \mathrm{O}, \mathrm{CH}_{4}, \mathrm{C}_{2} \mathrm{H}_{6}, \mathrm{C}_{3} \mathrm{H}_{8}$, aldehydes, $\mathrm{C}_{4} \mathrm{H}_{4}$, and $\mathrm{c}_{-} \mathrm{C}_{5} \mathrm{H}_{6}$ were observed at the low inlet temperature range (i.e., around $900 \mathrm{~K}$ ). Maximum mole fractions of $\mathrm{CO}_{2}, \mathrm{CO}, \mathrm{C}_{2} \mathrm{H}_{2}, \mathrm{C}_{3} \mathrm{H}_{3}, \mathrm{C}_{4} \mathrm{H}_{2}$ and aromatic species were observed at the high temperature range (i.e., $\geq 1100 \mathrm{~K}$ ).

The main pathways of $\mathrm{C}_{6} \mathrm{H}_{6}$ formation and the contributing species were investigated. Around the inlet temperature of $1100 \mathrm{~K}, \mathrm{C}_{3} \mathrm{H}_{6}$ and $\mathrm{C}_{2} \mathrm{H}_{4}$ were found to be the main species contributing to the formation of $\mathrm{C}_{6} \mathrm{H}_{6}$. For the inlet temperature of $1300 \mathrm{~K}, \mathrm{C}_{3} \mathrm{H}_{6}, \mathrm{C}_{2} \mathrm{H}_{4}$, and $\mathrm{C}_{3} \mathrm{H}_{3}$ were the contributing species to $\mathrm{C}_{6} \mathrm{H}_{6}$ formation in the oxidation of $n$-butane/DME mixture. The addition of DME affected the $\mathrm{C}_{6} \mathrm{H}_{6}$ formation pathways only in the higher temperature range.

The detailed chemical kinetic mechanism developed was reduced into a skeletal mechanism with much lower number of elementary reactions for the sake of simplicity. The number of the elementary reactions was reduced by $79 \%$, and the number of the participating chemical species by $49 \%$. The accuracy of the skeletal mechanism was tested by comparison with the literature and the results of the detailed mechanism. The skeletal mechanism can be used in complex multidimensional models for n-butane/DME oxidation without much loss of accuracy.

\section{ACKNOWLEDGMENT}

The authors thank State Planning Organization (2003K 120690) and Izmir Institute of Technology Scientific Research Fund (2008 IYTE 11) for financial supports.

\section{LITERATURE CITED}

1. Fleisch, T.H., Basu, A., \& Sills, R.A. (2012). Introduction and advancement of a new clean global fuel: The status of DME developments in China and beyond, Journal of Natural Gas Science and Engineering, 9, 94107.

2. Marchionna, M., Patrini, R., Sanfilippo, D., \& Migliavacca, G. (2008). Fundamental investigations on di-methyl ether (DME) as LPG substitute or make-up for domestic uses, Fuel Processing Technology, 89, 1255-1261.

3. Lee, S., Oh, S., \& Choi, Y. (2009). Performance and emission characteristics of an SI engine operated with DME blended LPG fuel, Fuel, 88, 1009-1015.

4. Yeom, K., \& Bae, C. (2009). Knock characteristics in liquefied petroleum gas (LPG) - dimethyl ether (DME) and gasoline - DME homogeneous charge compression ignition engines, Energy \& Fuels, 23, 1956-1964.

5. Lee, D., Lee, J.S., Kim, H.Y., Chun, C.K., James, S.C., \& Yoon, S.S. (2012). Experimental study on the combustion and NOx emission characteristics of DME/LPG blended fuel using counterflow burner, Combustion Science and Technology, 184, 97-113.

6. Hu, E., Jiang, X., Huang, Z., Zhang, J., Zhang, Z., \& Man, X. (2013). Experimental and kinetic studies on ignition delay times of dimethyl ether/n-butane $/ \mathrm{O}_{2} / \mathrm{Ar}$ mixtures, Energy \& Fuels, 27, 530-536.

7. Lim, O.T., \& Iida, N. (2012). The investigation about the effects of thermal stratification in combustion chamber on HCCI combustion fueled with DME/n-butane using rapid compression machine, Experimental Thermal and Fluid Science, 39, 123-133. 
8. Bekat, T., \& Inal, F. (2014). The effects of dimethyl ether on n-butane oxidation, Fuel, 115, 861-869.

9. U.S. Environmental Protection Agency (2002). Health assessment document for diesel engine exhaust (Final 2002). EPA/600/8-90/057F. Washington DC: Office of Research and Development, National Center for Environmental Assessment.

10. Marinov, N.M., Pitz, W.J., Westbrook, C.K., Vincitore, A.M., Castaldi, M.J., Senkan, S.M., \& Melius, C.F. (1998). Aromatic and polycyclic aromatic hydrocarbon formation in a laminar premixed n-butane flame, Combustion and Flame, 114, 192-213.

11. Kaiser, E.W., Wallington, T.J., Hurley, M.D., Platz, J., Curran, H.J., Pitz, W.J., \& Westbrook, C.K. (2000). Experimental and modeling study of premixed atmosphericpressure dimethyl ether-air flames, Journal of Physical Chemistry A, 104, 8194-8206.

12. Bekat, T. (2011). Effects of dimethyl ether on n-butane oxidation, MSc Thesis, Turkey: Izmir Institute of Technology.

13. Chakir, A., Cathonnet, M., Boettner, J.C., \& Gaillard, F. (1989). Kinetic study of n-butane oxidation, Combustion Science and Technology, 65, 207-30.

14. Fischer, S.L., Dryer, F.L., \& Curran, H.J. (2000). The reaction kinetics of dimethyl ether. I: High- temperature pyrolysis and oxidation in flow reactors, International Journal of Chemical Kinetics, 32, 713-740.

15. Chemkin-Pro. (2008). Reaction Design, San Diego.

16. Levenspiel, O. (1999). Chemical reaction engineering (3rd Edition), NJ: Wiley.

17. Lu, T., \& Law, C.K. (2005). A directed relation graph method for mechanism reduction, Proceedings of the Combustion Institute, 30, 1333-1341.

18. U.S. Environmental Protection Agency. (2013). Inventory of U.S. greenhouse gas emissions and sinks: 1990-2011. EPA 430-R-13-001, Washington, DC: U.S. Environmental Protection Agency.

19. U.S. National Toxicology Program. (2011). Report on carcinogens (12th edition). Research Triangle Park, NC: U.S. Department of Health and Human Services, Public Health Service.

20. Wilk, R.D., Cohen, R.S., \& Cernansky, N.P. (1995). The oxidation of n-butane: Transition in the chemistry across the region of negative temperature coefficient, Industrial and Engineering Chemistry Research, 34, 2285-2297.
21. Cole, J.A., Bittner, J.D., Longwell, J.P., \& Howard, J.B. (1984). Formation mechanism of aromatic compound in aliphatic flames, Combustion and Flame, 56, 51-70.

22. Dean, A.M. (1990). Detailed kinetic modeling of autocatalysis in methane pyrolysis, Journal of Physical Chemistry, 94, 1432-1439.

23. Bockhorn, H., Fetting, F., \& Wenz, H.W. (1983). Investigation of the formation of high molecular hydrocarbons and soot in premixed hydrocarbon-oxygen flames, Berichte Der Bunsengesellschaft Für Physikalische Chemie, 87, 1067-1073.

24. Frenklach, M., Taki, S., Durgaprasad, M.B., \& Matula, R.A. (1983). Soot formation in shock-tube pyrolysis of acetylene, allene, and 1,3-butadiene, Combustion and Flame, 54, 81-101

25. Badger, G.M, Lewis, G.E., \& Napier, I.M. (1960). The formation of aromatic hydrocarbons at high temperatures. Part VIII. The pyrolysis of acetylene, Journal of the Chemical Society, 2825-2827.

26. Hidaka, Y., Nakamura, T., Miyauchi, A., Shiraishi, T., \& Kawano, H. (1989). Thermal decomposition of propyne and allene in shock waves, International Journal of Chemical Kinetics, 21, 643-666.

27. Stein, S.E., Walker, J.A., Suryan, M.M., \& Fahr, A. (1991). A new path to benzene in flames, Proceedings of the Combustion Institute, 23, 85-90.

28. D'Anna, A., \& Violi, A. (1998). A kinetic model for the formation of aromatic hydrocarbons in premixed laminar flames, Proceedings of the Combustion Institute, 27, 425-433.

29. Hague, E.N., \& Wheeler, R.V. (1929). The mechanism of thermal decomposition of the normal paraffins, Journal of the Chemical Society (Resumed), 378-393.

30. Dente, M., Ranzi, E., \& Goossens, A.G. (1979). Detailed prediction of olefin yields from hydrocarbon pyrolysis through a fundamental simulation model (SPYRO), Computers \& Chemical Engineering, 3, 61-75.

31. Wu, C.H., \& Kern, R.D. (1987). Shock-tube study of allene pyrolysis, Journal of Physical Chemistry, 91, 6291-6296.

32. Yoon, S.S., Anh, D.H., \& Chung, S.H. (2008). Synergistic effect of mixing dimethyl ether with methane, ethane, propane, and ethylene fuels on polycyclic aromatic hydrocarbon and soot formation, Combustion and Flame, 154, 368-377. 